\title{
HEAVY METALS, URANIUM AND THORIUM IN AGRICULTURAL SOILS AND PLANTS FROM THE BUHOVO REGION, BULGARIA
}

\author{
Tanja Stoilkova $^{1}$, Vasilka Mladenova ${ }^{1}$, Dimitrina Dimitrova $^{2}$ \\ ${ }^{1}$ Department of Mineralogy, Petrology and Economic Geology, Faculty of Geology and Geography, \\ Sofia University "St. Kliment Ohridski\#", 15 Tsar Osvoboditel Blvd., Sofia 1504, Bulgaria \\ ${ }^{2}$ Geological Institute, Bulgarian Academy of Sciences \\ Acad. G. Gonchev Str.. bl. 24, 1113 Sofia, Bulgaria \\ tstoilkova@gea.uni-sofia.bg
}

\begin{abstract}
A b s t r a c t: Ten soil and five plant samples from private gardens in Buhovo town and from the agricultural area between Buhovo town and Yana village, Bulgaria, were investigated. Inductively coupled plasma mass spectrometry was used for the determination of $\mathrm{Cu}, \mathrm{Pb}, \mathrm{Zn}, \mathrm{Cd}, \mathrm{Hg}, \mathrm{Ni}, \mathrm{As}, \mathrm{Cr}, \mathrm{U}$ and $\mathrm{Th}$ concentrations. The results showed higher concentrations of $\mathrm{Pb}$ and $\mathrm{As}$ in soil samples. The highest contents of $\mathrm{U}$ and $\mathrm{Th}$ were determined in soils collected from private gardens in Buhovo town and sample collected from the Manastirska riverside. Among the plant samples, the highest uptake of $\mathrm{Pb}, \mathrm{As}, \mathrm{Cr}$ and $\mathrm{Cu}$ were established for the sunflower and wheat stems. The comparison of soil and plant samples U/Th ratios clearly indicate uranium enrichment of the sunflower and thorium enrichment of the wheat samples. In the wild briar, hawthorn and reed fruits the contents of $U$ and $T h$ were below the detection limit.
\end{abstract}

Key words: uranium; heavy metals; soils; plants; Buhovo uranium ore field

\section{INTRODUCTION}

Heavy metals are released into the environment by both natural (naturally occurring radioactive materials - NORM) and anthropogenic sources (technologically enhanced naturally occurring radioactive material - TENORM). Generally, the natural concentration of heavy metals in agricultural soils, derived from soil parent materials, normally is not sufficiently high to harm human health (ATSDR, 2018). However, anthropogenic sources such as mining, waste disposal, urban effluent, sewage sludge, and agrochemicals can greatly increase heavy metal concentrations in agricultural soils (Kabata-Pendias, 2011). The presence of $\mathrm{As}, \mathrm{Cd}, \mathrm{Co}, \mathrm{Cu}, \mathrm{Pb}, \mathrm{Zn}$, $\mathrm{Ni}, \mathrm{Hg}, \mathrm{U}, \mathrm{Th}$ in the environment is of great ecological significance due to their toxicity, translocation through food chains and their non-biodegradability which is responsible for their accumulation in the biosphere (Opaluwa et al., 2012, Rahman et al., 2012, Arogujo et al., 2009). Uranium has both radiotoxicity and chemical toxicity, whereas thorium is to be considered as only radiotoxic.
Uranium mining in Bulgaria started in 1942 at the Buhovo ore field. It is located around $25 \mathrm{~km}$ north of Sofia. The ore field was one of the largest uranium mining and processing areas in Bulgaria, covering an area of approximately $70 \mathrm{~km}^{2}$ until its closure in 1992. The ore was mined underground by means of 7 schafts and 150 mine galleries with total length around $55 \mathrm{~km}$. As a result 198 dumps and tailings ponds with a total volume of $4 \mathrm{Mm}^{3}$ rock waste are disposed in the area. The amount of extracted uranium is $4219.4 \mathrm{t}$ (Dikov and Bozhkov, 2014). Two tailings impoundments, covering an area of 100 ha have been constructed near the processing factory. They contain about $5.8 \mathrm{Mm}^{3}$ uranium tailing waste which is a complex mixture of waste rock material, radionuclides, $\mathrm{Pb}, \mathrm{Zn}, \mathrm{As}, \mathrm{Cu}$ and other heavy metals in the form of sulfates, carbonates, nitrates and complex compounds. Waterproof protection layers were not installed at the bottom of the tailings impoundments at their construction thus some water soluble compounds could seep into the environment (Arhangelova et al., 2010a) . 
Only a few studies concerning the contents and the distribution of heavy metals in soils around Buhovo town have been performed. Arhangelova et al. (2010a, 2010b) reported elevated $\mathrm{Pb}$ and As concentrations in the meadow soils samples near the Buhovo mine. The values of specific activity of ${ }^{238} \mathrm{U},{ }^{232} \mathrm{Th}$ and ${ }^{40} \mathrm{~K}$ reported to be within the admissible range.

Inductively coupled plasma mass spectrometry (ICP-MS) was used for the determination of $U$ and Th contents, ${ }^{238} \mathrm{U} /{ }^{232} \mathrm{Th}$ and ${ }^{235} \mathrm{U} /{ }^{238} \mathrm{U}$ ratios (Mihaylova et al., 2013). The results showed that the Th and $U$ concentrations in the soils were over 50 times higher than the background values, although the sampling sites were not shown. The U/Th ratio was markedly higher than the control value, suggesting contamination with uranium. The concentrations of $\mathrm{U}$ and $\mathrm{Th}$ in dandelion, wheat and grass collected near the radioecologically problematic area were found to be higher in comparison with plant samples from unpolluted area.

This study reports the contents of heavy metals, $\mathrm{U}$ and $\mathrm{Th}$ in agricultural soils and plants in the vicinity of Buhovo town and adjacent reclaimed tailings impoundment.

\section{STUDY AREA}

The Buhovo ore field comprises around 10 uranium deposits which are genetically and spatially related to the Buhovo-Seslavtsi pluton and some are hosted in it. Buhovo-Seslavtsi pluton outcrops on the surface as a small $(2.5 \times 3 \mathrm{~km})$ stock of monzonite, syenite and quartz-syenite with a gradual transition between them. The syenites and monzonites are cut by dykes of various compositions in the following order of emplacement: syenite-aplite, microsyenites (bostonites) and peralkaline syenite to granite-porphyries (Dyulgerov and Platevoet, 2009). Quaternary materials overlay the primary rocks in the southern part of the studied area.

The host rocks of the uranium deposits are: 1) mainly Silurian argillite and shale with high content of organic matter; 2) rarely - the magmatic rocks; and 3) occasionally - the Ordovician argillite and shale. The tectonic fractures are ore-controlling. The metasomatic ore bodies are stocks, lenses and veins with inconstant uranium content. The main primary mineral is uraninite (pitchblende) associated with other minerals, such as pyrite, chalcopyrite, tennantite, galena, sphalerite, calcite, dolomite and ankerite. Torbernite and autunite occur in the near surface zone. Other rare secondary minerals identified in the deposits are kasolite, soddvite, uranocircite, phosphoruranilite, sabugalite, dewindtite and bessetite (Kalaidjiev, 2009).

\section{MATERIALS AND METHODS}

\section{Soil and plant sampling}

In September 2015, nine soil samples (S1-7, S9-10) were collected from the upper soil layer (5$25 \mathrm{~cm}$ depth) and one sample (S8) was taken from 25 to $40 \mathrm{~cm}$ depth according to the ISO 10381-1:2005 and ISO 10381-2:2005. The sampling location of $\mathrm{S} 7, \mathrm{~S} 8$ and $\mathrm{S} 9$ is from private gardens in Buhovo town where heavy metal industrial contamination is less likely possible. The samples S7 and S8 were taken at one place, but from different depth. The other soil samples were gathered from agricultural areas between the tailings impoundment and Yana village. The weight of each sample was $\sim 1 \mathrm{~kg}$. Five plant samples - wheat stems (P1), reed (Typha) stems and leaves (P2), sunflower (Helianthus annu$u s$ ) heads and upper parts of the stems (P3), wild briar (Rosa canina) fruits $(\mathrm{P} 4)$ and hawthorn $(\mathrm{Cra}$ taegus monogyna) fruits (P5) were collected as well. The sampling sites of plants and soils are closely located (Figure 1).

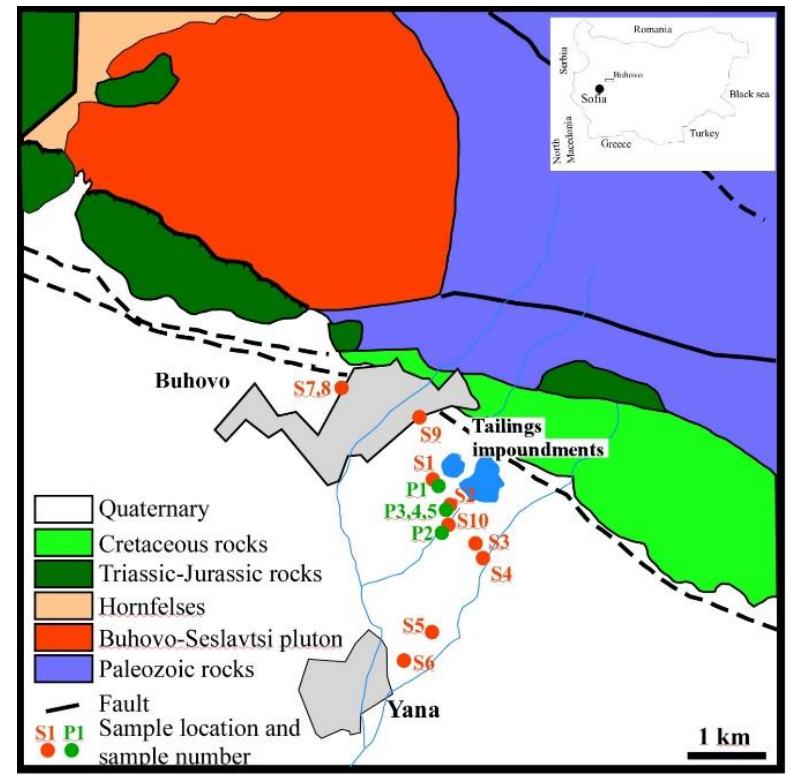

Fig. 1. Simplified sketch map of Buhovo region with sampling points of soils $(\mathrm{S})$ and plants $(\mathrm{P})$ (modified after Angelov, 2010). 


\section{Sample preparation}

Soil samples. The samples were air-dried, homogenized and sieved. A $3-5 \mathrm{~g}$ portions of $<0.063$ $\mathrm{mm}$ fractions were analyzed. The chemical analyses were performed at the Acme Labs - Canada, using ICP-MS in accordance with ISO/IEC-17025:2005.

The soils $\mathrm{pH}$ was measured using $1: 2.5$ (wt : wt) ratio of soil sample and deionized water. The mixtures were stored at $25^{\circ} \mathrm{C}$, homogenized five times and $\mathrm{pH}$ was measured after $16 \mathrm{~h}$.

Plant samples. The samples were oven-dried at $60^{\circ} \mathrm{C}$ for $10 \mathrm{~h}$ and milled. After that, $0.5 \mathrm{~g}$ of the sample was mixed with $20 \mathrm{ml}$ acid solution $(1: 1: 1$ $\mathrm{HNO}_{3}: \mathrm{HCl}: \mathrm{H}_{2} \mathrm{O}$ ) and digested in microwave. The analysis was performed using ICP-MS at the Acme Labs.

\section{RESULTS AND DISCUSSION}

\section{Heavy metals contents in soils}

The measured and the recommended concentration of $\mathrm{Cu}, \mathrm{Ni}, \mathrm{Zn}, \mathrm{Pb}, \mathrm{Cd}, \mathrm{Cr}, \mathrm{As}, \mathrm{Hg}, \mathrm{U}$, Th as well as the $\mathrm{U} / \mathrm{Th}$ ratio and $\mathrm{pH}$ (slightly acidic to neutral, $6.85-7.36$ ) of soil samples are showed in Figure 2 and Table 1.

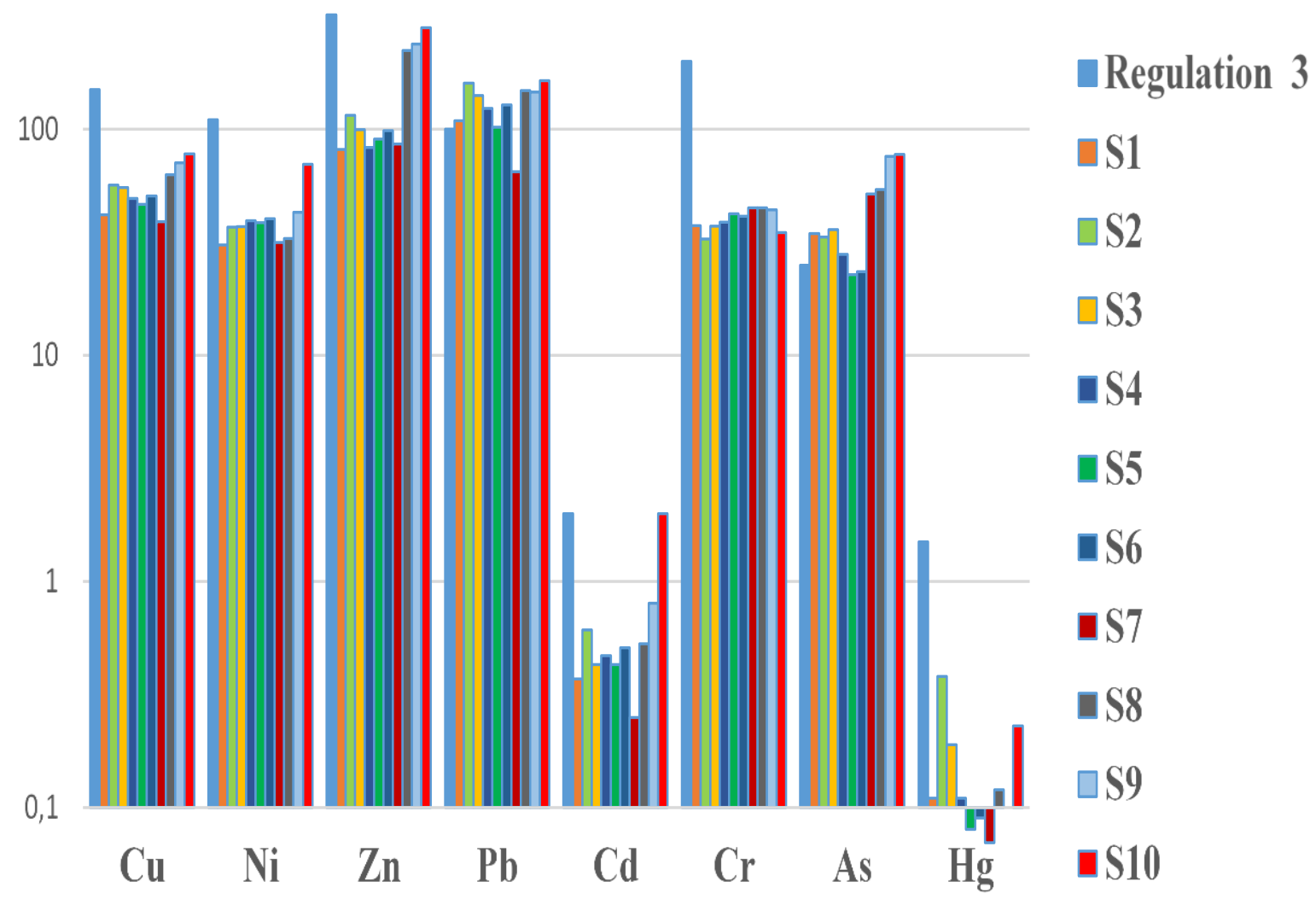

Fig. 2. Heavy metals concentrations $(\mathrm{mg} / \mathrm{kg})$ in soil samples

Table 1

$\mathrm{pH}, U$ and Th concentrations $(\mathrm{mg} / \mathrm{kg})$ in soil samples

\begin{tabular}{lllllllllll}
\hline \hline & S1 & S2 & S3 & S4 & S5 & S6 & S7 & S8 & S9 & S10 \\
\hline $\mathbf{p H}$ & 6.88 & 6.85 & 7.02 & 7.28 & 7.33 & 7.40 & 6.89 & 7.38 & 7.3 & 7.36 \\
$\mathbf{U}$ & 1.6 & 1.8 & 1.2 & 1.1 & 0.8 & 0.7 & 2.2 & 2.7 & 2.6 & 43.0 \\
Th & 7.4 & 5.6 & 8.0 & 7.9 & 7.5 & 6.8 & 25.2 & 20.8 & 6.0 & 7.7 \\
$\mathbf{U} / \mathbf{T h}$ & 0.22 & 0.32 & 0.15 & 0.14 & 0.11 & 0.10 & 0.09 & 0.13 & 0.4 & 5.58 \\
\hline \hline
\end{tabular}


The results showed that the concentrations of $\mathrm{Cu}, \mathrm{Ni}, \mathrm{Zn}, \mathrm{Cd}, \mathrm{Cr}$ and $\mathrm{Hg}$ in all soil samples were below the recommended by the Bulgarian Regulation № 3, 2008 (Figure 2.). The $\mathrm{Pb}$ contents in nine samples were higher than recommended levels. Only in S7 soil sample the $\mathrm{Pb}$ value was lower -65 $\mathrm{mg} / \mathrm{kg}$. The S10 sample was collected from the Manastirska riverside. Manastirska river drains the Buhovo tailings impoundment and therefore the concentration of all heavy metals and $\mathrm{U}$ in S10 sample were higher in comparison to other samples. In the same S10 sample, the highest concentration of $\mathrm{Pb}(163.7 \mathrm{mg} / \mathrm{kg})$ was detected, which was 1.5 times more than standard value. The analytical results for the As values showed lower levels in S5 and S6 samples. The As concentrations in other soils were two to three times higher than the recommended (Bulgarian Regulation № 3, 2008).

The heavy metals in S7 (surface) and S8 (depth) samples showed increased concentrations of $\mathrm{Cu}, \mathrm{Pb}, \mathrm{Zn}, \mathrm{Cd}$ and $\mathrm{Hg}$ in the depth. Therefore, the rock forming substrate origin of the heavy metals was assumed (Tomovski et al., 2019, Dyulgerov, 2005). Uranium and thorium contents in uncontaminated soils worldwide vary within the range of 1.9 $4.4 \mathrm{mg} / \mathrm{kg}$ and $8.1-11 \mathrm{mg} / \mathrm{kg}$, respectively (Kabata-Pendias, 2011). The highest uranium concentration was measured in sample $S 10(43 \mathrm{mg} / \mathrm{kg})$, while the Th content was $7.7 \mathrm{mg} / \mathrm{kg}$ (Table 1). The calculated U/Th ratios indicate small variations of 0.09 (S1) to $0.43 \mathrm{mg} / \mathrm{kg}$ (S9). Only for the soil sample S10 it was $5.6 \mathrm{mg} / \mathrm{kg}$ (Table 1), suggesting contamination with uranium. Additionally, decreasing contents of $\mathrm{Zn}, \mathrm{As}, \mathrm{U}$ and $\mathrm{Th}$ from Buhovo town
(S7, S8, S9) towards Yana village (S1, S2, S3, S4, S5 and S6) were observed. These higher values in samples from Buhovo town could possibly be due to the participation of Buhovo-Seslavtsi pluton rocks and uranium minerals in the soil formation process as these rocks are enriched in As, $\mathrm{U}$ and $\mathrm{Th}$ (Dyulgerov, 2005).

In the vicinity of the Yana village Paleozoic and Mesozoic sedimentary rocks containing small quantities of heavy metals have contributed in the soil forming process. Therefore, the concentrations of $\mathrm{Cu}, \mathrm{Ni}, \mathrm{Zn}, \mathrm{Pb}, \mathrm{Cd}, \mathrm{Cr}, \mathrm{As}, \mathrm{Hg}, \mathrm{U}$ and $\mathrm{Th}$ in the agricultural soil samples decreased in north-southern direction from Buhovo town to Yana village.

\section{Heavy metals contents in plants}

The contents of heavy metals $(\mathrm{Cu}, \mathrm{Ni}, \mathrm{Zn}, \mathrm{Pb}$, $\mathrm{Cd}, \mathrm{Cr}, \mathrm{As}, \mathrm{Hg}, \mathrm{U}, \mathrm{Th}$ ) and $\mathrm{U} / \mathrm{Th}$ ratio in the plant samples are presented in Table 2. The measured concentrations of $\mathrm{Pb}, \mathrm{As}, \mathrm{Cd}$ and $\mathrm{Hg}$ were compared to the values listed in Regulation № 10, 2009. Lead and arsenic contents in wheat stem and sunflower heads were higher than recommended, whereas $\mathrm{Cd}$ and $\mathrm{Hg}$ were within the permissible concentration ranges for all plant samples.

Low levels of $\mathrm{Cu}, \mathrm{Zn}$ and $\mathrm{Cr}(\mathrm{III})$ are essential for humans, animals and plants. They are necessary for maintaining good health of the organisms (ATSDR, 2018). However, high levels, particularly of $\mathrm{Cr}(\mathrm{VI})$, can cause harmful effects depending on the dosage, duration of intake and the route of exposure. The highest concentrations of $\mathrm{Cr}$ were detected in wheat stems and in sunflower.

Table 2

Heavy metals, $U$ and Th concentrations $(\mathrm{mg} / \mathrm{kg})$ in plant samples

\begin{tabular}{lcccccc}
\hline \hline & $\begin{array}{c}\text { Regulation } \\
\text { № 10 }\end{array}$ & $\begin{array}{c}\text { P1 } \\
\text { wheat steams }\end{array}$ & $\begin{array}{c}\text { P2 } \\
\text { reed }\end{array}$ & $\begin{array}{c}\text { P3 } \\
\text { sunflower }\end{array}$ & $\begin{array}{c}\text { P4 } \\
\text { wild briar }\end{array}$ & $\begin{array}{c}\text { P5 } \\
\text { hawthorn }\end{array}$ \\
\hline $\mathbf{C u}$ & - & 6.56 & 5.9 & 20.11 & 4.38 & 3.69 \\
$\mathbf{N i}$ & - & 6.2 & 1.6 & 5.3 & 0.5 & 0.7 \\
$\mathbf{Z n}$ & - & 24 & 133.5 & 40 & 9.1 & 9.5 \\
$\mathbf{P b}$ & 10 & 10.67 & 1.12 & 14.46 & 0.07 & 0.25 \\
$\mathbf{C d}$ & 1 & 0.21 & 0.05 & 0.24 & $<0.01$ & 0.04 \\
$\mathbf{C r}$ & - & 13.7 & 5.3 & 8.0 & 1.5 & 1.5 \\
$\mathbf{A s}$ & 2 & 2.9 & 0.2 & 3.1 & $<0.01$ & $<0.01$ \\
$\mathbf{H g}$ & 0.1 & 0.017 & 0.021 & 0.039 & 0.004 & 0.002 \\
$\mathbf{U}$ & - & 0.15 & 0.03 & 0.22 & $<0.01$ & $<0.01$ \\
$\mathbf{T h}$ & - & 0.9 & $<0.01$ & 0.37 & $<0.01$ & $<0.01$ \\
$\mathbf{U} /$ Th & - & 0.17 & - & 0.59 & - & - \\
\hline \hline
\end{tabular}


The highest $\mathrm{Zn}$ contents $(133.5 \mathrm{mg} / \mathrm{kg})$ was found in reed (stem and leaves). This is probably due to reed's preferential absorption of $\mathrm{Zn}$ and the soil substrate, which is probably enriched in $\mathrm{Zn}$, situated near S10 soil sample, showing the highest trace elements content.

The $\mathrm{U}$ and $\mathrm{Th}$ contents in the wheat and sunflower were considerably higher in comparison to reed, the fruits of wild briar and hawthorn. The wheat and sunflower samples were collected from the places of S1 and S2 soil samples, respectively. The comparison of their U/Th ratios clearly indicate uranium enrichment of the sunflower and thorium enrichment of the wheat samples. According to Kabata-Pendias (2011) the contents of U and Th in the plants vary widely within a broad range and follow their occurrence in soils. Wheat is known to accumulate amounts from 0.0032 to $0.019 \mathrm{mg} / \mathrm{kg}$, whereas sunflower from 0.043 to $0.24 \mathrm{mg} / \mathrm{kg}$. In the wild briar, hawthorn and reed fruits the contents of $\mathrm{U}$ and $\mathrm{Th}$ were below the detection limit.

\section{CONCLUSIONS}

The aim of this research was to provide an assessment of heavy metals contamination in agri- cultural soil and plants cultivated or grown on these soils. Due to weathering processes all rocks in the area take part in the soil formation.

The lead and arsenic contents in the soil samples were higher than recommended values. The highest concentrations of $\mathrm{U}, \mathrm{Th}$ and As were measured in soil samples collected from Buhovo town. These soils have been formed close to the uranium deposits related to the Buhovo-Seslavtsi pluton.

The Manastirska River drains the Buhovo tailings impoundment therefore the concentration of all heavy metals and $U$ in the sample from its waterfront were higher compared to the other samples.

The contents of heavy metals, $U$ and $T h$ in the agricultural soil samples decrease in north-southern direction due to the increasing of distance from the uranium deposits.

Among the plant samples sunflower and wheat stems showed higher values of $\mathrm{Pb}, \mathrm{As}, \mathrm{Cr}$ and $\mathrm{Cu}$ than recommended. The U/Th ratio showed that the sunflower and wheat were enriched of $\mathrm{U}$ and $\mathrm{Th}$, respectively.

Acknowledgments: This study was supported financially by the Sofia University Science Fund - grant Nr. 146/2014 and by the National Science Fund Grant DNTS China 01/7.

\section{REFERENCES}

Agency for Toxic Substances and Disease Registry (ATSDR), U. S. Department of health and Human Services (2018). (https://www.atsdr.cdc.gov/toxfaqs/index.asp)

Angelov, V., Chrischev, Ch., (Eds), 2010: Geological Map of Bulgaria 1:50 000, Map sheet Elin Pelin.

Arhangelova, N., Berovski, K., Dikov, D., Kostov, L., Mladenov, M., Penev, I. Protohristov, H., Stojanov, Ch., Todorov, S., Hristov, H., Velev, V., Ushev, S., Uzunov, N. (2010a): Contents of natural radionuclides in the mine Buhovo region, International Scientific Conference “UNITEH”, Gabrovo, III, 397-401.

Arhangelova, N., Nikolova, E., Berovski, K., Dikov, D., Kostov, L., Kostov, R., Mladenov, M., Protohristov, H., Uzunov, N. (2010b): Quantitative elemental analysis of samples from mine Buhovo region, International Scientific Conference "UNITEH", Gabrovo, III, 402-406.

Arogujo, A. M., Höllriegl, V., Giussani, A., Leopold, K., Gerstmann, U., Veronese, I., Oeh, U. (2009): Uranium and thorium in soils, mineral sands, water and food samples in a tin mining area in Nigeria with elevated activity, Journal of Environmental Radioactivity, 100, 232-240.

Dikov, D., Bozhkov, I. (2014:): Uranium deposits in Republic of Bulgaria - state of art and potential, Review of the Bulgarian Geological Society, 75, № 1-3, 131-137.

Dyulgerov, M. (2005): Le Plutonisme de Tendance Alcalin Potassique de Stara Planina, Bulgarie: Etude Petrologique des Complexes de Buhovo-Seslavzi, Svidnja et Shipka. $\mathrm{PhD}$ Thesis, Univsrsite Paris XI, Orsay, France, p. 310.
Dyulgerov, M., Platevoet, B. (2009): Comparative mineralogical study of mafic minerals from Variscan potassic-alkaline rocks in Stara Planina Mountains, Bulgaria, Review of the Bulgarian Geological Society, 70, № 1-3, 47-62.

Kabata-Pendias A. (2011): Trace elements in soils and plants (Fourth edition), CRC Press, Taylor@Francis Group

Kalaidjiev, S. (2009): Metallogenic problems of the Balkanides. Review of the Bulgarian Geological Society, 70, № $1-3,222-242$.

Mihaylova, V., Todorov, B., Djingova, R. (2013): Determination of uranium and thorium in soils and plants by ICPMS. Case study of Buhovo region, Comptes Rendus de l'Académie Bulgare des Science, 66, №4, 513-518.

Opaluwa, O. D., Aremu, M. O., Ogbo, L. O., Abiola, K. A., Odiba, I. E., Abubakar, M. M. and Nweze, N. O. (2012): Heavy metal concentrations in soils, plant leaves and crops grown around dump sites in Lafia Metropolis, Nasarawa State, Nigeria, Advances in Applied Science Research, 3, № 2, 780-784.

Rahman S. H., Khanam, D., Adyel, T. M., Islam, M. S., Ahsam, M. A., Akbor, M. A. (2012): Assessment of heavy metal contamination of agricultural soil around Dhaka Export Processing Zone (DEPZ), Bangladesh: implication of seasonal variation and indices, Applied Science, 2, 584-601.

Regulation № 3 (2008): Bulgarian limit values of harmful substances in soils, Ministry of Environmental and Water, (http://www.moew.government.bg/, in Bulgarian). 
Regulation № 10 (2009): Bulgarian limit values of harmful substances in fodders, Ministry of Environmental and Water, (http://www.moew.government.bg/, in Bulgarian).
Tomovski D., Andonovska K. B., Šajn R., Karadjov M., Stafilov T. (2019): Distribution of chemical elements in sediments and alluvial soils from the Crna Reka river basin, Geologica Macedonica, 33, №2, 125-145.

\title{
Р е $з$ и м е
}

\section{ТЕШКИ МЕТАЛИ, УРАНИУМ И ТОРИУМ ВО ПОЧВИТЕ И РАСТЕНИЈАТА ОД ОБЛАСТА НА БУХОВО, БУГАРИЈА}

\author{
Тања Стоилкова ${ }^{1}$, Василка Младенова $^{1}$, Димитрина Димитрова ${ }^{2}$

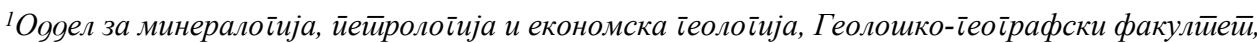

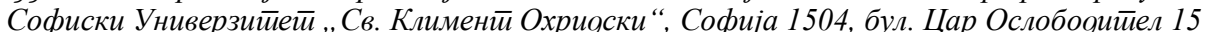

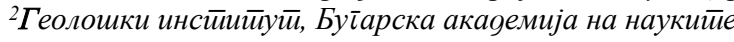 \\ бул, Акая.Г.Бончев, 24, 1113 Софија, Буіарија \\ tstoilkova@gea.uni-sofia.bg
}

Клучни зборови: ураниум; тешки метали; почви; растенија; ураниумова рудна област Бухово

Испитувани се 10 примероци почва и 5 примероци растенија земени од приватни градини во градот Бухово и од земјоделски површини помеѓу градот Бухово и селото Јана, Бугарија. За определување на концентрацијата на $\mathrm{Cu}, \mathrm{Pb}$, $\mathrm{Zn}, \mathrm{Cd}, \mathrm{Hg}, \mathrm{Ni}, \mathrm{As}, \mathrm{Cr}, \mathrm{U}$ и Th беше користена масена спектрометрија со индуктивно спрегната плазма (ICP-MS). Peзултатите покажаа повисоки концентрации на $\mathrm{Pb}$ и $\mathrm{As}$ во примероците почва. Висока содржина на U и Th беше утврдена во примероците на почва од приватни градини од градот Бухово и од брегот на Манастирска Река. Кај растенијата висока содржина на $\mathrm{Pb}, \mathrm{As}, \mathrm{Cr}$ и $\mathrm{Cu}$ беше удврдена во примероците сончоглед и во стеблото на пченица. Споредбата на односот U/Th во примероците на почвата и на растенијата јасно покажа збогатување со ураниум во сончогледот и со ториум во пченицата. Содржината на $\mathrm{U}$ и $\mathrm{Th}$ во шипки и во плодовите на глог и трска беше под границите на детекција. 